\title{
Ocorrência de septoriose em Crotalaria spectabilils no Estado de Mato Grosso, Brasil
}

\author{
Antonio Carlos Maringoni ${ }^{1}$, Márcio Veronese ${ }^{2}$ e Carlos Alexandre Costa Crusciol $^{1}$
}

${ }^{1}$ Faculdade de Ciências Agronômicas, UNESP, CP 237, 18603-970 Botucatu-SP. ²Fundação MT, CP 79, 78750-000 Rondonópolis-MT Autor para correspondência: Antonio Carlos Maringoni (maringoni@fca.unesp.br)

Data de chegada: 24/04/2012. Aceito para publicação em: 06/12/2012.

A leguminosa Crotalaria spectabilis é empregada na adubação verde, em solos com baixa fertilidade, e no manejo de áreas infestadas com nematóides causadores de galhas e migradores (Inomoto, M. et al. Nematologia Brasileira, v.30, p.39-44, 2006) . Poucas informações estão disponíveis na literatura sobre doenças desta leguminosa. Durante dezembro de 2007, houve um surto de doença que causava manchas foliares (Figura 1 A) e queda prematura de folhas, em um cultivo comercial de C. spectabilis, localizado em Jaciara, MT. Folhas doentes foram encaminhadas para análise, junto à Clínica Fitopatológica, do Departamento de Produção Vegetal, FCA/UNESP, no início de 2008. Após a submissão de folhas em câmara úmida, por 24-48 h, sob condições laboratoriais, foi possível realizar análises microscópicas que revelaram a presença de picnídios com abundante presença de conídios finos, hialinos e septados, estruturas fúngicas pertencentes

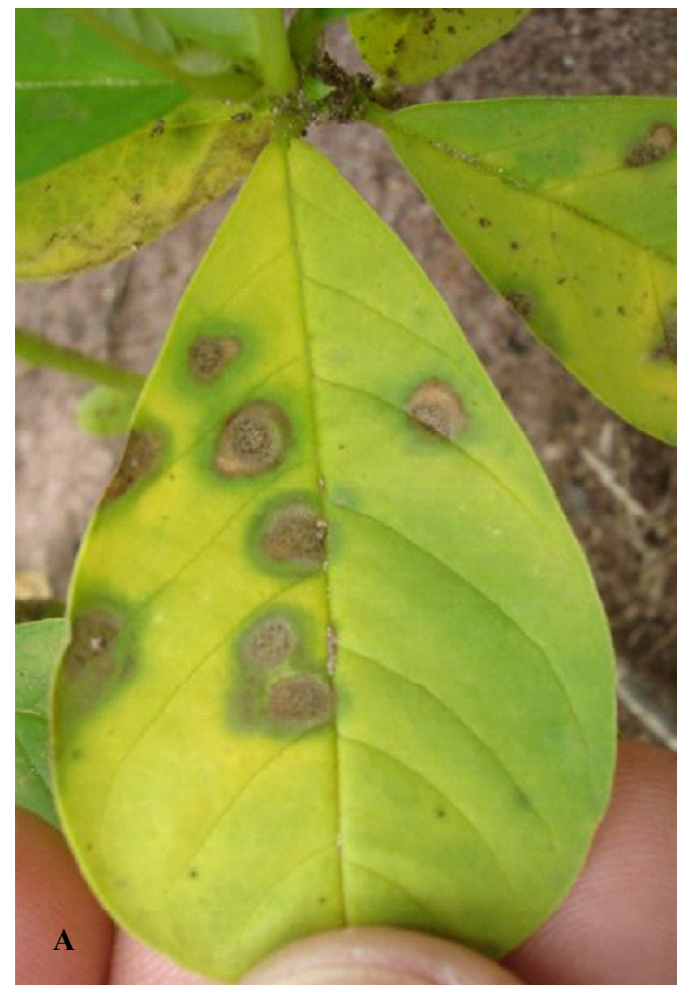

ao gênero Septoria, Figura 1B, (H.L. Barnett et al. Illustrated genera of impefect fungi, 1998, 218p). Em consulta à bibliografia, foi possível identificar a espécie do fungo, que se trata de Septoria.crotalariae. Esta espécie fúngica foi identificada e descrita por A.P. Viégas, em 1945, em folhas de C. spectabalis, provenientes de uma lavoura da Fazenda Santa. Elisa, IAC, Campinas, SP (A.P. Viégas, Bragantia, v.5, p.745, 1945). Posteriormente, em 2011, após 66 anos da primeira constatação deste patógeno em C. spectabilis na Fazenda Santa Elisa (IAC), em Campinas, houve um novo surto epidêmico da doença que causou desfolha severa nas plantas afetadas (Ito, M.F. et al. Summa Phytopathologica, v. 38, supl, p.102. 2012). Propõem-se a denominação de septoriose para a doença causada por $S$. crotalariae em C. spectabilis. Este é o primeiro relato da septoriose em C. spectabilis no Estado do Mato Grosso, Brasil.

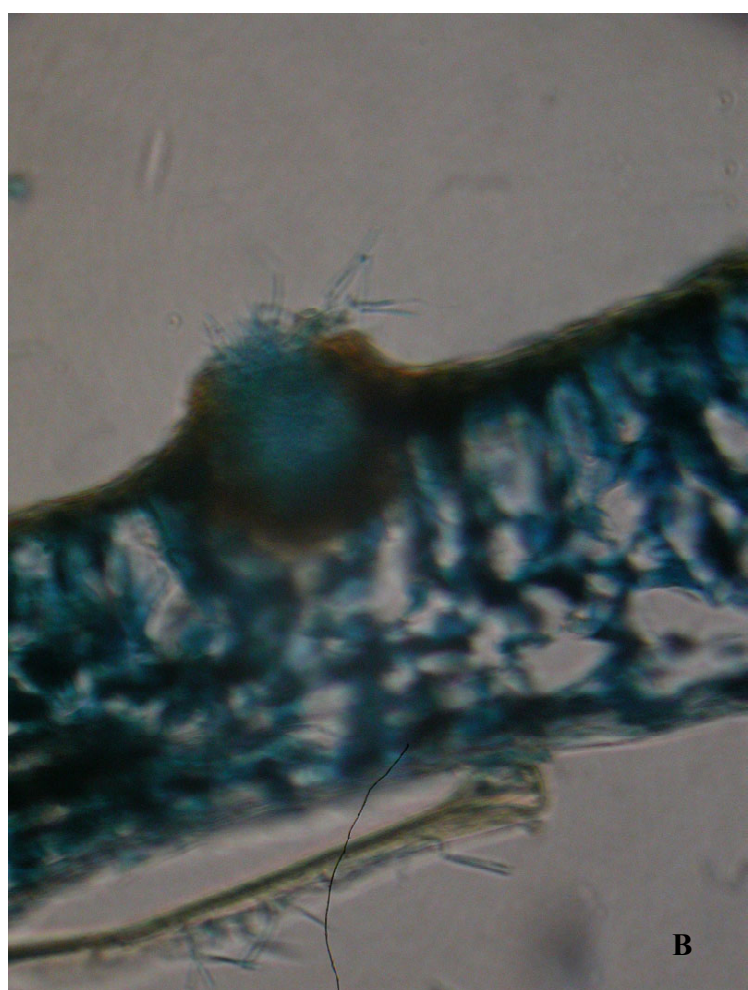

Figura 1. Sintomas de septoriose em folhas de Crotalaria spectabilis (A) e microfotografia de picnídio e conídios de Septoria crotalariae observado na folha (B). 